Competitive Strategies for the 21st Century 



\section{Competitive Strategies for the 21st Century}

THEORY, HISTORY, AND PRACTICE

Edited by Thomas G. Mahnken 
Stanford University Press

Stanford, California

(C) 2012 by the Board of Trustees of the Leland Stanford Junior University.

All rights reserved.

No part of this book may be reproduced or transmitted in any form or by any means, electronic or mechanical, including photocopying and recording, or in any information storage or retrieval system without the prior written permission of Stanford University Press.

Printed in the United States of America on acid-free, archival-quality paper

Library of Congress Cataloging-in-Publication Data

Competitive strategies for the 21st century : theory, history, and practice / edited by Thomas G. Mahnken.

pages $\mathrm{cm}$

"This volume grew out of a conference on 'Developing Competitive Strategies for the 21st Century,' which was held at the U.S. Naval War College in Newport, Rhode Island in August 2010."

Includes bibliographical references and index.

ISBN 978-0-8047-8241-8 (cloth : alk. paper) -

ISBN 978-0-8047-8242-5 (pbk. : alk. paper)

1. United States-Foreign relations-China-Congresses. 2. China-Foreign relationsUnited States-Congresses. 3. United States-Foreign relations-21st century-

Congresses. 4. National security-United States-Congresses. 5. Strategic rivalries

(World politics)_Congresses. I. Mahnken, Thomas G., editor of compilation.

E183.8.C5C67 2012

327.7305109 '05-dc23

2011052146

Special discounts for bulk quantities of Stanford Security Studies are available to corporations, professional associations, and other organizations. For details and discount information, contact the special sales department of Stanford University Press.

Tel: (650) 736-1782, Fax: (650) 736-1784

Typeset by Thompson Type in 10/14 Minion 
To Andrew W. Marshall, mentor and friend 
